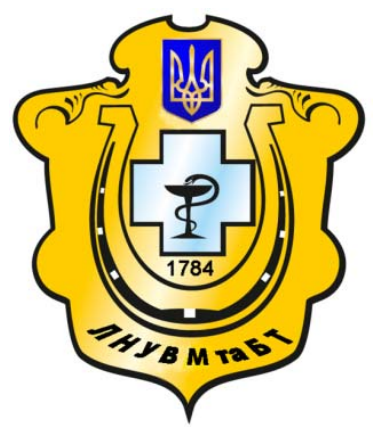

Науковий вісник Львівського національного університету ветеринарної медицини та біотехнологій імені С.3. Гжицького

Scientific Messenger of Lviv National University of Veterinary Medicine and Biotechnologies named after S.Z. Gzhytskyj

doi:10.15421/nvlvet6826

ISSN 2413-5550 print

ISSN 2518-1327 online

$\underline{\text { http://nvlvet.com.ua/ }}$

УДК 664.14:664.8

\title{
Технологія виробництва кондитерських напівфабрикатів 3 порошками з банану та моркви
}

\author{
М.В. Янчик, О.В. Драненко, О.В. Нєміріч \\ marfysha_777@mail.ru,dranenko94@meta.ua, avnemirich@mail.ru \\ Національний університет харчових технологій, \\ вул. Володимирська, 68, м. Київ, 01601, Украӥна
}

\begin{abstract}
Сьогодні спостерігається проблема дефіциту нутрієнтів в харчуванні населення економічно розвинутих краӥн, що пов'язано з різким зниженням енерговитрат і зміною рачіону харчування, який не забезпечує сформованих фізіологічних потреб у цілому ряді незамінних харчових речовин. Ефективним способом ліквідації дефіциту нутрієнтів є збагачення ними харчових продуктів масового споживання до рівня, що відповідає фізіологічним проблемам людини.

Кондитерські вироби є групою харчових продуктів широкого асортименту, які значно відрізняються між собою за складом і споживчими характеристиками. Вони користуються сталим попитом насамперед завдяки вишуканим смаковим властивостям. Споживання кондитерських виробів відіграє значну роль у повноиінному харчуванні різних вікових груп населення, особливо у дітей. Основні групи виробів в даній галузі займають боромняні кондитерські вироби. Для їх оформлення використовують різноманітні оздоблювальні напівфабрикати: глазурі, помадні маси, креми. Значення кондитерських виробів у харчуванні зумовлено високою енергетичною цінністю, яка забезпечується значним вмістом иукрів, а в деяких виробах i жирів, але їх харчова иінність обмежена. Тому було розроблено технологію кондитерських напівфабрикатів із використанням рослинних порошків, вершкового масла та поверхнево активної речовини - ефіру лимонної кислоти. В якості контролю для збагачення обрано класичну помаду иукрову. Обтрунтовано вибір сировини, розроблено технологічну схему з детальним описом стадій виробництва. Визначено органолептичні (зовнішній вигляд, смак та запах, колір, консистенція) та фізико-хімічні (масові частки вологи та жиру, вміст редукуючих речовин та розмір кристалів основної фракції) показники якості готових напівфабрикатів. Показано переваги нового кондитерського напівфабрикату за органолептичними показниками якості у порівнянні з контролем. Отриманий кондитерський напівфабрикат підвищеної харчової иінності є багатофункціональним та дозволяє розширити асортимент оздоблювальних напівфабрикатів закладів ресторанного господар-
\end{abstract} ства.

Ключові слова: кондитерський напівфабрикат, технологія, рослинні порошки, показники якості, кондитерські вироби, підвищена харчова изінність.

\section{Технология производства кондитерских полуфабрикатов с порошками из банана и моркови}

\author{
М.В. Янчик, О.В. Драненко, А.В. Немирич \\ marfysha_777@mail.ru,dranenko94@meta.ua, avnemirich@mail.ru \\ Национальный университет пищеевых технологий, \\ ул. Владимирская, 68, г. Киев, 01601, Украина
}

Сегодня наблюдается проблема дефицита нутриентов в питании населения экономически развитых стран, что связано с резким снижением энергозатрат и изменением рациона питания, который не обеспечивает сформированных физиологических потребностей в иелом ряде незаменимых пищевых веществ. Эффективным способом ликвидации дефицита нутриентов является обогащение ими пищевых продуктов массового потребления до уровня, соответствующего физиологическим проблемам человека.

Ianchyk M.V., Dranenko O.V., Niemirich O.V. (2016). Technology of confectionery semifinished with bananas and carrots. Scientific Messenger LNUVMBT named after S.Z. Gzhytskyj, 18, 2(68), 130-133. 
Кондитерские изделия являются группой пищевых продуктов иирокого ассортимента, значительно отличаются между собой по составу и потребительскими характеристиками. Они пользуются устойчивым спросом в первую очередь благодаря изысканным вкусовым свойствам. Потребление кондитерских изделий играет значительную роль в полноценном питании различных возрастных групп населения, особенно у детей. Основные группь изделий в данной области занимают мучные кондитерские изделия. Для их оформления используют различные отделочные полуфабрикаты: глазури, помадные массы, кремы. Значение кондитерских изделий в питании обусловлено высокой энергетической иенностью, которая обеспечивается высоким содержанием сахаров, а в некоторых изделиях, и жиров, но их пищевая ценность ограничена. Поэтому была разработана технология кондитерских полуфабрикатов с использованием растительных порошков, сливочного масла и поверхностно активного вещества - эфира лимонной кислотьл. В качестве контроля для обогащения выбрана классическая помада сахарная. Обоснован выбор сырья, разработана технологическая схема с подробньм описанием стадий производства. Определены органолептические (внешний вид, вкус и запах, иявет, консистенция) и физико-химические (массовые доли влаги и жира, содержание редуцирующих веществ и размер кристаллов основной фракции) показатели качества готовьх полуфабрикатов. Показаны преимущества нового кондитерского полуфабриката по органолептическим показателям в сравнении с контролем. Полученный кондитерский полуфабрикат повышенной пищевой ценности является многофункциональным и позволяет расширить ассортимент отделочных полуфабрикатов заведений ресторанного хозяйства.

Ключевые слова: кондитерский полуфабрикат, технология, растительные порошки, показатели качества, кондитерские изделия, повышенная пищевая иенность.

\title{
Technology of confectionery semifinished with bananas and carrots
}

\author{
M.V. Ianchyk, O.V. Dranenko, O.V. Niemirich \\ marfysha_777@mail.ru,dranenko94@meta.ua, avnemirich@mail.ru \\ National University of Food Technologies, \\ Volodymyrska Str., 68, Kyiv, 01601, Ukraine
}

Today there is observed problem of deficit of nutrients in food of the population of economically developed countries that is connected with sharp decrease of energy costs and change of a diet which doesn't provide the created physiological needs for a number of irreplaceable nutrients. In an efficient manner liquidation of deficit of nutrients is enrichment of foodstuff of mass consumption by them to the level corresponding to physiological problems of the person is.

Confectionery are group of foodstuff of a wide assortment, considerably differ in composition and consumer characteristics. They are in steady demand first of all thanks to the exquisite taste properties. Consumption of confectionery plays a significant role in the balanced diet of various age groupes of the population, especially at children. Primary groups of products in the field occupy by pastry. For their registration use various finishing semifinished products: icing, fondant masses and creams.

Value of confectionery products in nutrition is caused by the high energy value which is provided by the high content of sugars, and in some products by fats, but their nutrition value is limited. Therefore the technology of confectionery semi-finished products with use of plant powders, butter and superficially active agent - citric acid ester was developed. As a control sample for enrichment was chosen classical sugar fondant. The raw materials choice is substantiated, the technological scheme with the detailed description of production stages is developed. Indicators of quality of ready semifinished products are determined, such as organoleptic (appearance, taste and a smell, color, a consistency) and physicochemical (mass fractions of moisture and fat, content of the reducing substances and the size of crystals of the main fraction). Benefits of a new confectionery semifinished product on organoleptic indicators in comparison with control are shown. The received confectionery semi-finished product of the increased nutrition value is multifunctional and allows expanding the range of finishing semi-finished products in institutions of restaurant economy.

Key words: confectionery semi-finished product, technology, plant powders, quality indicators, confectionery, the increased nutrition value.

\section{Вступ}

Розширення асортименту кондитерської продукції закладів ресторанного господарства, підвищення їх харчової цінності є актуальним завданням науковців і практиків. Як свідчить аналіз сучасних публікацій, сьогодні досліджують та вдосконалюють параметри технологічних процесів, збагачують ягідними, фруктовими, овочевими пюре, порошками, екстрактами (Milner, 2002; Dudenko, 2006; Korecjka, 2008; Maghomedov et al., 2015). Серед широкого асортименту харчових продуктів борошняні кондитерські вироби 3 оздоблювальними напівфабрикатами є одними 3 найбільш енергоємних (Snjezhkin et al., 2002; Omeljchenko et al., 2015). Поступова заміна традиційного асортименту харчових продуктів на функціональні є основним напрямом розвитку сучасного ринку. У зв'язку з цим, проаналізувавши сучасні дослідження у сфері оздоблювальних напівфабрикатів, ми дій- шли до висновку про створення універсального кондитерського напівфабрикату, що значно скоротить час технологічного процесу на виробництві та матиме підвищену харчову та смакову цінність.

Метою роботи було створення кондитерського напівфабрикату із підвищеною харчовою цінністю 3 використанням натуральної рослинної сировини.

\section{Матеріал і методи досліджень}

Кондитерські вироби, а саме оздоблювальні напівфабрикати є зручним об'єктом для збагачення, оскільки особливо популярно використовуються для надання виробам приємного вигляду та смаку. Проаналізувавши рецептурний склад оздоблювальних напівфабрикатів, виявлено, що основними складовими інгредієнтами $\epsilon$ цукор, патока, вода, вершкове масло. Таким чином, для зразка збагачення ми вибрали помаду цукрову, яку збагачуємо вершковим маслом, 
ПАР та натуральними інгредієнтами - рослинними порошками.

В якості матеріалів для збагачення оздоблювальної помади обрано порошки з бананів та моркви, що мають масову частку вологи 5\% та дисперсність $10 . .20$ мкм. Дані порошки мають високі органолептичні властивості, а саме - виражені смак та аромат. Банановий порошок є джерелом харчових волокон, органічних кислот, калію та магнію. Морквяний порошок містить достатню кількість органічних кислот та $\beta$ каротину. Окрім цього, грає роль природного барвника, що значно розширює сферу використання напівфабрикату та робить готові продукти більш привабливими для споживання.

Додавання вершкового масла зробить основу напівфабрикату більш пластичною: механічний вплив, при подальшому його використанні, буде проводити значно легше, так як і отримати потрібну форму при оздобленні. Воно забезпечуватиме краще засвоєння $\beta$-каротину порошка з моркви у кондитерському напівфабрикатів. Результати дослідження помадних мас показали, що для кращих структурно-механічних

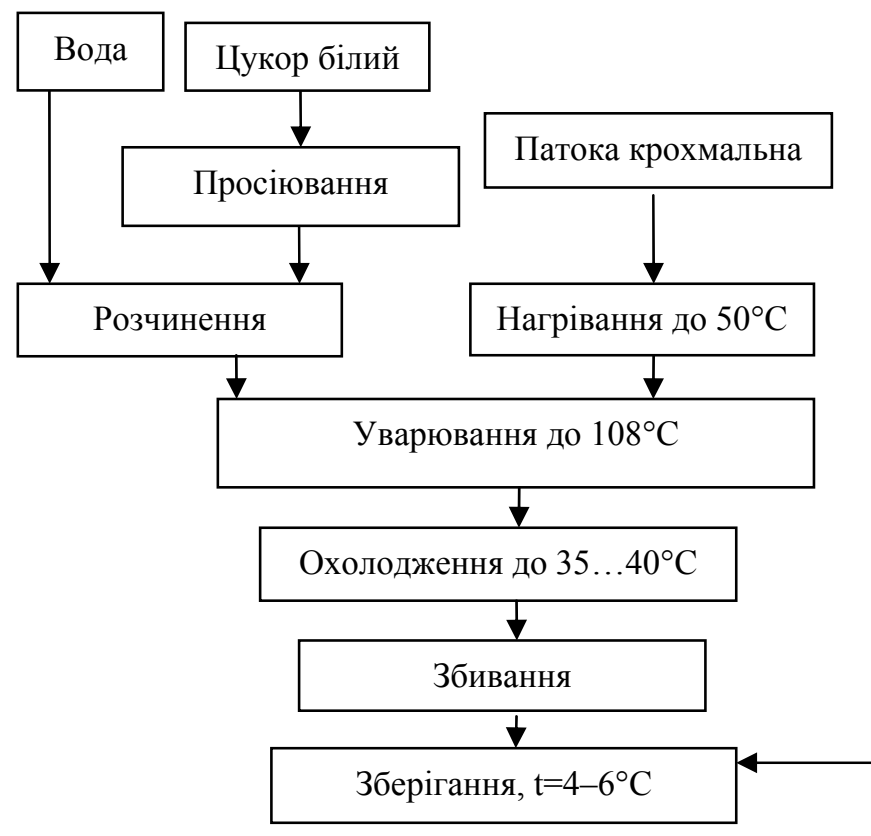

\section{Рис. 1. Технологічна схема виробництва кондитерських напівфабрикатів 3 порошками з бананів та моркви}

У ємність засипають цукор, заливають його гарячою водою та розчиняють цукор при помішуванні. Сироп уварюють до $108{ }^{\circ} \mathrm{C}$. Під час кипіння бризки сиропу на стінках казана перетворюються на кристали цукру, які, потрапляючи назад у сироп, викликають його кристалізацію. Щоб цього не трапилося, сироп варять при закритій кришці. При цьому паротворення під кришкою запобігає утворенню кристалів на стінках казана, змиваючи їх конденсатом води. Після розчинення цукру змивають мокрою щіточкою 3 внутрішніх стінок кристали цукру, збільшують нагрів і варять сироп без помішування. Піну видаляють 3 поверхні розчину. Нагрівання повинне бути швидким (на сильному вогні), повільне нагрівання призведе до потемніння помади. властивостей важливо вносити ПАР на етапі введення порошково-масляної суміші, це дозволяє утримувати відповідну консистенцію при впливі температур. Ефір лимонної кислоти, моно-, дигліцерид (Е 472 с) - поверхнево-активна речовина, яка додається у обов'язковій кількості $0,5 \%$ від маси напівфабрикату та допомагає тримати однорідну структуру при багатократному тепловому та механічному впливі.

\section{Результати та їх обговорення}

Технологія нового кондитерського напівфабрикату 3 фруктовим та овочевим порошками, маслом вершковим і ПАР передбачає наступні етапи: підготовка сировини до виробництва, приготування порошковомасляної суміші, приготування помадної маси і змішування отриманих інгредієнтів (рис. 1). Процес виготовлення помади полягає в одержанні цукрової маси дрібнокристалічної структури, що досягається уварюванням цукрово-патокового сиропу до визначеної концентрації з наступним охолодженням і збиванням сиропу.

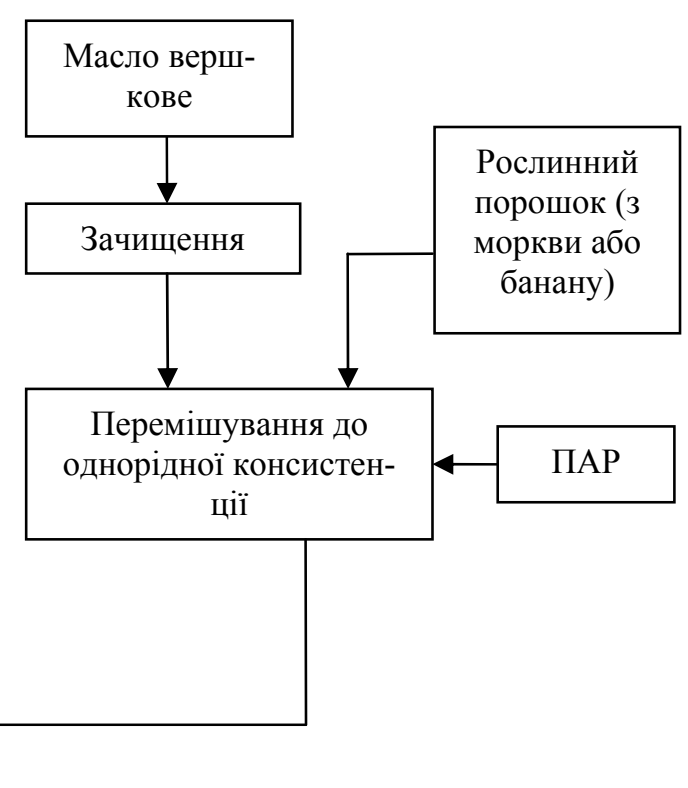

Далі у сироп додають нагріту до $50{ }^{\circ} \mathrm{C}$ патоку, при цьому щільність сиропу зменшується, тому продовжують уварювання до проби на м'яку кульку. Патока оберігає сироп від зацукрювання і сприяє утворенню дрібніших кристалів при збиванні, в результаті помада виходить вищої якості. Приготовлений помадний сироп швидко охолоджують до $35-40{ }^{\circ} \mathrm{C}$, оскільки при повільному охолоджуванні утворюються кристали, і помада виходить грубою.

Паралельно готують суміш вершкового масла 3 рослинним порошкам та ПАР для введення у кондитерський напівфабрикат. У вершкове масло при температурі $20{ }^{\circ} \mathrm{C}$ додають рослинний порошок (з банану або моркви) та ПАР (ефір лимонної кислоти). Отри- 
ману суміш ретельно перемішують до однорідної консистенції.

Охолоджений помадний сироп до $35-40{ }^{\circ} \mathrm{C}$ збивають. При цій температурі утворюються найдрібніші кристали і зберігається така в'язкість сиропу, яка не ускладнює збивання помади. Якщо температура буде вища, то при збиванні утворюються крупні кристали, i якість помади погіршає. При низькій температурі помада виходить 3 дрібними кристалами, проте важче збивається, оскільки в густому сиропі сповільнюється кристалізація цукру.

Під час збиття сироп поступово каламутнішає, зберігаючи якийсь час ту ж в'язкість. Зовнішньою ознакою початку утворення помади є побіління маси. Одночасно 3 цим різко збільшується їі в'язкість і підвищується температура, що є ознакою виділення кристалів На цьому етапі, продовжуючи збивання, поступово додають порошково-масляну суміш. Додавання інгредієнтів при низьких температурних режимах $\left(35-40{ }^{\circ} \mathrm{C}\right)$ дозволяє зберегти всі вітаміни та поживні речовини.

Результати дослідження органолептичних та фізико-хімічних показників кондитерських напівфабрикатів, збагачених рослинними порошками, наведені у табл. 1 .

Органолептичні та фізико-хімічні показники якості кондитерських напівфабрикатів, збагачених рослинними порошками

\begin{tabular}{|c|c|c|c|}
\hline \multirow[t]{2}{*}{ Показники } & \multirow{2}{*}{$\begin{array}{l}\text { Помада цукрова } \\
\text { (контроль) }\end{array}$} & \multicolumn{2}{|c|}{ Кондитерський напівфабрикат } \\
\hline & & 3 порошком 3 моркви & 3 порошком з банану \\
\hline Зовнішній вигляд & \multicolumn{3}{|c|}{ Блискуча маса з нелипкою поверхнею } \\
\hline Смак та запах & $\begin{array}{l}\text { Нейтральний, } \\
\text { солодкий }\end{array}$ & \begin{tabular}{|c|} 
Приємний, з присмаком та \\
запахом моркви, без відчутних \\
часточок порошку
\end{tabular} & \begin{tabular}{|c|} 
Приємний, $з$ добре відчутним \\
смаком та запахом банану, без \\
відчутних часточок порошку
\end{tabular} \\
\hline Колір & Білий & Помаранчевий, однорідний & Світло-жовтий, однорідний \\
\hline Консистенція & $\begin{array}{l}\text { Тверда, неплас- } \\
\text { тична }\end{array}$ & \multicolumn{2}{|c|}{ Однорідна, пластична } \\
\hline Масова частка вологи,\%, не більше & 12 & 12,2 & 11,6 \\
\hline Масова частка жиру, \% & - & 25 & 18 \\
\hline $\begin{array}{c}\text { Вміст редукуючих речовин,\%, не } \\
\text { менше } \\
\end{array}$ & 4,8 & 4,4 & 4,2 \\
\hline Розмір кристалів основної фракції, мкм & $10-15$ & $10-15$ & $10-15$ \\
\hline
\end{tabular}

Як видно з табл. 1, новий кондитерський напівфабрикат $є$ переважним в порівнянні 3 контролем за органолептичними показниками, а саме має приємний смак та запах відповідний кожному виду порошку, набуває яскравих кольорів, що дозволяє розширити асортимент продукції. Основною перевагою отриманого напівфабрикату є пластична консистенція, що полегшує подальше його використання та відкриває нові перспективи застосування.

\section{Висновки}

Сукупність всіх інгредієнтів дозволяє одержати універсальний оздоблювальний напівфабрикат з особливою рецептурою, підвищеною харчовою цінністю, смаковими властивостями та багатофункціональністю, який можна використовувати в якості глазурі, крему, начинки, а також як самостійний продукт. Розроблено технологію виробництва універсального напівфабрикату із використанням нетрадиційної рослинної сировини та визначено основні показники його якості.

Перспективи подальших досліджень. В подальшому планується визначення перерозподілу форм зв'язків в модельних зразках методом термогравіметричного аналізу, що одночасно дозволяє проводити виміри температури досліджуваного зразка, зміну його маси та швидкості зміни маси. Дослідження окисно-відновних характеристики шляхом визначен- ня функціональних чисел впродовж терміну зберігання.

\section{Бібліографічні посилання}

Dudenko, N.V. (2006). Fizyko-khimichni ta biotekhnologhichni osnovy tekhnologhiji ghaluzi. Metodychni rekomendaciji ta zavdannja dlja vykonannja laboratornogho praktykumu. Kh., 27-34 (in Ukrainian).

Korecjka, I.V. (2008). Boroshnjani kondytersjki vyroby z roslynnymy poroshkamy nabuvajutj stijkykh likuvaljnoprofilaktychnykh vlastyvostej. Khlibopekarsjka i kondytersjka promyslovistj. 11, 35-36 (in Ukrainian).

Maghomedov, Gh.O., Lobosova, L.A., Maghomedov, M.Gh. (2015). Vlijanije ovoshhnykh poroshkov na pokazately kachestva sbivnykh izdelij. Zhurnal «Konditerskoe proizvodstvo». 4, 11-13 (in Russian).

Omeljchenko, S.B., Ghoraljchuk, A.B., Fedak, N.V. (2015). Vyznachennja racionaljnykh parametriv tekhnologhichnogho procesu vyrobnyctva ozdobljuvaljnykh napivfabrykativ. Scientific Journal «ScienceRise». 2/2(7), 73-77.

Snjezhkin, Ju.F., Shapar, R.O., Kharin, O.O. (2002). Dosvid vykorystannja naturaljnykh poroshkiv $\mathrm{z}$ roslynnoji syrovyny u molochnykh produktakh. Promyshlennaja teplotekhnyka. 24, 4, 57-59 (in Ukrainian).

Milner, J.A. (2002). Functional foods and health: a US perspective. British Journal Nutrition. 88(1.2), 151-158.

Стаття надійшла до редакиії 17.09.2016 